\title{
Penanaman Nilai Kejujuran Saat Ujian Nasioal di SMK Nurul Iman Palembang
}

\author{
Disti Liana \\ Universitas Palembang \\ distilianaeko@gmail.com
}

\begin{abstract}
Almost every year education in Indonesia is always shrouded in problems especially when national exam will be held. Problems that arise like cramming, compressing National Exam subjects by leaving other lessons, forming successful teams, and giving sanctions to Schools that fail the National Exam, and others. Supposedly, the National Exam is the answer in our efforts to realize an honest and achieving education process. This study aims to determine how the teacher's efforts in inculcating the value of honesty during the National Examination at Vocational High School Nurul Iman Palembang. This research is a field research with qualitative approach. To obtain data in this research, researcher use some methods in collecting data that are observation, interview and documentation. Data analysis technique used is descriptive technique. The result of the research is the cultivation of honesty value during the National Exam in Vocational High School Nurul Iman Palembang, among others: First, appealed and advised the students to study hard at home and school and take the best time to learn. Second, hold impromptu evaluation. Third, cultivating faith in God confesses that there is no god but Allah, always remember Allah wherever located so afraid to commit sins or errors intentionally even if not known by others. Fourth, explain the honest benefits of the National Examination.
\end{abstract}

Keywords: Honesty Value, National Examination

Abstrak: Hampir setiap tahun pendidikan di Indonesia selalu diselimuti permasalahan terutama ketika ujian nasional akan diselenggarakan. Permasalhan yang muncul seperti belajar kebut semalam, memadatkan mata pelajaran Ujian Nasional dengan meninggalkan pelajaran lain, membentuk tim sukses, dan memberi sangsi kepada Sekolah yang gagal Ujian Nasional, dan lainnya. Mestinya, Ujian Nasioanal adalah jawaban dalam upaya kita mewujudkan proses pendidikan yang jujur dan berprestasi. Penelitian ini bertujuan untuk mengetahui bagaimana upaya guru dalam menanamkan nilai kejujuran saat Ujian Nasioal di SMK Nurul Iman Palembang. Penelitian ini adalah penelitian lapangan yang dengan pendekatan kualitatif. Untuk memperoleh data dalam penelitian ini, peneliti menggunakan beberapa metode dalam pengumpulan data yaitu 
observasi, wawancara dan dokumentasi. Teknik analisis data yang digunakan adalah teknik deskriptif. Hasil penelitian yaitu penanaman nilai kejujuran saat Ujian Nasional di SMK Nurul Iman Palembang antara lain: Pertama, menghimbau dan menasehati siswa untuk rajin belajar baik di rumah maupun di sekolah serta memanfaatkan waktu belajar dengan sebaik-baiknya. Kedua, mengadakan evaluasi dadakan. Ketiga, memupuk iman kepada Allah mengakui bahwa tiada Tuhan selain Allah, selalu mengingat Allah dimanapun berada sehingga takut untuk melakukan dosa atau kekeliruan dengan sengaja sekalipun tidak diketahui orang lain. Keempat, menjelaskan manfaat jujur saat Ujian Nasional.

Kata Kunci: Nilai Kejujuran, Ujian Nasional.

\section{Pendahuluan}

Akhlak ataupun budipekerti memegang peranan penting dalam kehidupan manusia. Akhlak yang baik akan membedakan antara manusia dengan hewan, manusia yang berakhlak mulia dapat menjaga kemuliaan dan kesucian jiwanya, dapat mengalahkan tekanan hawa nafsu syahwat syaitoniah, berpegang teguh kepada sendi-sendi keutamaan ajaran Islam, menghindarkan diri dari sifat-sifat kecurangan, kerakusan dan kezaliman, sebagaimana nabi s.a.w. bersabda yang artinya "Orang Mukmin yang paling sempurna imannya ialah yang paling baik akblaknya (H.R.Ahmad)". Sehingga Allah akan mengangkat derajat manusia yang berakhlak mulia ke derajat yang tinggi dan mulia.

Salah satu akhlak mulia yang harus tertanam dalam diri manusia adalah kejujuran, kejujuran merupakan sesuatu yang berada dalam diri manusia paling dalam. Dalam kondisi tertentu hanya orang yang bersangkutan dan tentunya Tuhan saja yang mengetahui jujur dan tidaknya seseorang. Sebagai muslim sudah seharusnya menanamkan budaya jujur dalam kehidupan seharihari karena sifat jujur telah diwariskan oleh Rasulullah. Misal jadi pedagang, pedagang yang jujur, jadi pegawai, pegawai yang jujur, jadi pejabat, pejabat yang jujur, jadi pemimpin, pemimpin yang jujur, agar masyarakat atau rakyat ini menjadi tenang dan makmur, karena kalau jujur sudah tertanam apapun pekerjaan kita, maka kita akan disenangi oleh banyak orang dan diridhai Allah SWT.

Bila kita membuka mata dan menatap Indonesia saat ini runtuhnya nilai kejujuran baik dalam segi politik, ekonomi, bahkan krisis kejujuranpun menjamur pada dunia pendidikan, dimana sekolah sekarang ini tidak lagi memperhatikan kemampuan siswa-siswi, guru datang terlambat ke sekolah, 
bahkan ada guru yang bolos dengan menelantarkan siswa-siswinya, terkadang guru masuk kelas hanya sekedar isi absen dan memberikan latihan kepada siswa tanpa menjelaskan materi. Sebagaimana hasil penelitian Erlisia Ungusari yaitu saat berada pada situasi kesulitan mengerjakan ujian dan melihat teman-teman saling menyontek, perilaku jujur yang muncul sebanyak $41,10 \%$ dan perilaku tidak jujur yang muncul sebanyak $58,90 \%{ }^{1}$

Hampir setiap tahun pendidikan di Indonesia selalu diselimuti permasalahan terutama ketika ujian nasional akan diselenggarakan. Perdebatan tentang perlu atau tidak perlu ujian negara dilaksanakan, rupanya akhir-akhir ini sudah tidak lagi dianggap perlu, bagi pemerintah ujian negara dianggap perlu karena merupakan pelaksanaan Undang.-Undang Sistem Pendidikan Nasional Pasal 58 ayat (1) dan (2). Tetapi teknis penentuan kelulusan diatur dalam Peraturan Pemerintah Nomor 19 Tahun 2005 tentang Standar Nasional Pendidikan. ${ }^{2}$ Namun, pada pelaksanaannya Ujian Nasional belum bisa dijadikan jawaban bagi kita untuk mengukur tingkat keberhasilan peserta didik dalam proses pembelajaran, karena dalam proses persiapan, pelaksanaan dan pasca Ujian Nasional, banyak sekali proses atau kebijakan yang diambil baik oleh Sekolah, guru, peserta didik dan bahkan daerah yang sebenarnya bertentangan dengan spirit pendidikan itu sendiri.

Pertanyaan yang seringkali muncul selama ini adalah mengapa penyimpangan ujian itu tampak sistematis, massif dan melibatkan banyak pihak, penyimpangan itu melibatkan kepala sekolah, guru dan kadang juga pemerintah daerah, untuk menjawab persoalan itu sesungguhnya tidak terlalu sulit, bagi kepala sekolah, guru dan pemerintah daerah karena ujian nasional bukan kepentingan pemerintah pusat. Bagi pejabat daerah diselenggarakannya Ujian Nasional bukan saja untuk mengetahui peta prestasi hasil pendidikan secara nasional dan juga pemenuhan amanah undang-undang. Ujian Nasional bagi mereka memiliki arti terkait dengan prestise daerah, termasuk prestise kepala sekolah dan para guru. Kita seringkali mendengar, bahwa biasanya sebelum ujian dilaksanakan maka ditetapkan target, misalnya sekian persen para siswa dalam ujian nasional harus lulus. Sebab, kelulusan ini terkait dengan nama baik pemerintah daerah dan juga sekolah yang bersangkutan, mereka tidak akan mau

\footnotetext{
${ }^{1}$ Erlisia Ungusari, 2015. Kejujuran dan Ketidakjujuran Akademik pada Siswa SMA yang Berbasis Agama. Fakultas Psikologi Universitas Muhammadiyah Surakarta.

${ }^{2}$ Undang-Undang Republik Indonesia Nomor 20 Tahun 2003 tentang SISDIKNAS dan Peraturan Pemerintah tentang Penyelenggaraan Pendidikan serta Wajib Belajar. (Bandung: Citra Umbara), 90.
} 
disebut bahwa hasil ujian sekolah di wilayahnya, misalnya jauh lebih rendah dari kabupaten atau kota lainnya.

Melihat kenyataan seperti itu, Ujian Nasional tidak saja bermaksud melihat peta prestasi pendidikan secara nasional semata, melainkan sudah terkait dengan berbagai kepentingan. Memperjuangkan kepentingan sama dengan bertaruh agar taruhannya menang maka apa saja dianggap syah dilakukan, termasuk dalam hal Ujian Nasional dengan memberikan bantuan menjawab soal-soal ujian, nafsu memenuhi kepentingan menjadikan obyektifitas, kejujuran, keadilan semuanya diabaikan. Apalagi pelaksanaan ujian juga melibatkan pihak luar, secara psikologis kehadiran pihak luar itu dianggap sebagai lawan bersama, kepala sekolah, guru, pimpinan daerah termasuk para siswa merasa berada pada satu barisan lalu berhadapan dengan pihak luar yakni pemerintah pusat bersama para pemantau dan termasuk pengawas dari perguruan tinggi tersebut. Logika seperti itulah yang mendorong di antara mereka melakukan penyimpangan ujian, bisa jadi, penyimpangan ujian bukan saja terjadi di sekolah-sekolah tertentu melainkan menyeluruh di semua tempat, bedanya di sekolah tertentu, penyimpangan itu ketahuan sedangkan di sekolah lain tidak, oleh karena itu persoalan Ujian Nasional ternyata bukan sederhana tetapi sudah masuk pada wilayah sosial yang amat luas.

Berkaitan dengan penelitian ini, SMK Nurul Iman salah satu SMK swasta di kota Palembang, SMK Nurul Islam Palembang adalah salah satu SMK di kota Palembang yang berlabelkan Islam sesuai dengan misi SMK Nurul Iman Palembang menciptakan siswa-siswi terampil dan berkualitas dengan bernafaskan Islami, dengan meletakan nilai-nilai Islami sebagai landasan dalam pendidikan. SMK Nurul Iman Palembang akan melaksanakan Ujian Nasional sama seperti sekolah-sekolah pada umumnya yang akan menghadapi Ujian Nasional. Berdasarkan uraian di atas, maka penulis berminat melakukan penelitian lebih lanjut tentang bagaimana penanaman nilai-nilai kejujuran pada saat Ujian Nasional di SMK Nurul Iman Palembang.

\section{Pembahasan}

\section{Nilai Kejujuran}

\section{a. Pengertian dan Keutamaan Jujur}

Nabi menganjurkan umatnya untuk selalu jujur karena kejujuran merupakan mukadimah akhlak mulia yang akan mengarahkan pemiliknya kepada akhlak tersebut, sebagaimana dijelaskan oleh Nabi, "Sesungguhnya 
kejujuran membawa kepada kebajikan”. Kebajikan adalah segala sesuatu yang meliputi makna kebaikan, ketaatan kepada Allah dan berbuat kebajikan pada sesama. Jujur merupakan modal dasar dalam kehidupan bersama dan kunci menuju keberhasilan. Melalui kejujuran kita dapat mempelajari, memahami, dan mengerti tentang keseimbangan-keharmonisan. Jujur terhadap peran pribadi, jujur terhadap hak dan tanggung jawab, jujur terhadap tatanan yang ada, jujur dalam berfikir, bersikap, dan bertindak. ${ }^{3}$

Kata "jujur" berasal dari Bahasa Arab "ash-shidqu” atau "shiddiq" yang artinya nyata, benar, atau berkata benar. Lawan katanya adalah "al- kadribu" yang berarti dusta (bohong). Dalam Kamus Besar Bahasa Indonesia, kata : “jujur merupakan kata dasar dari kejujuran yang berarti lurus hati; tidak berbohong (misal berkata apa adanya); tidak curang (misal dalam permainan mengikuti aturan yang berlaku); tulus; ikhlas. Sedangkan kejujuran berarti sifat (keadaan) jujur; ketulusan (hati); kelurusan (hati): ia meragukan kejujuran anak muda itu". Menurut Agus Wibowo, “jujur diartikan sebagai perilaku yang didasarkan pada upaya menjadikan dirinya sebagai orang yang selalu dapat dipercaya dalam perkataan, tindakan dan pekerjaan". 5

Sebagai contoh dalam kehidupan sehari-hari seorang yang jujur dalam bermuamalah dengan orang lain maka dilancarkan rezekinya dan orang lainpun berlomba-lomba datang untuk bermuamalah dengannya karena merasa tenang bersamanya dan mendapatkan kemulian. Dengan begitu sempurnalah baginya kebahagian dunia dan akhirat. Seorang yang beriman dan jujur, tidak berdusta dan tidak mengucapkan kecuali kebaikan.

Berapa banyak ayat dan hadist yang menganjurkan untuk jujur diantaranya sebagai berikut: ${ }^{6}$

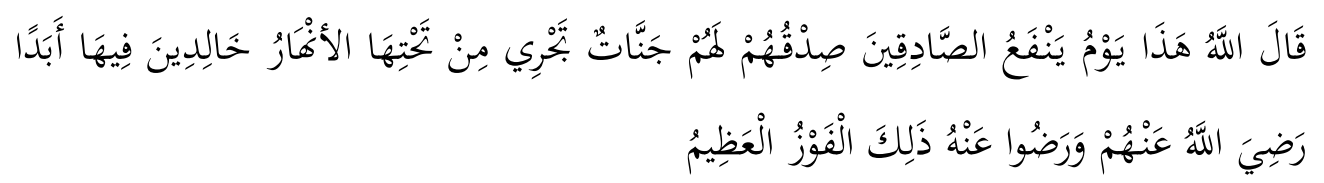

${ }^{3}$ Nina Sultonurohmah, Strategi Penanaman Nilai Karakter Jujur Dan Disiplin Siswa, AlIbtida',Vol. 5, No. 2, 2017. STAI Diponegoro Tulungagung.

4 W.J.S. Poerwadarminta, Kamus Besar Bahasa Indonesia, (Jakarta: Balai Pustaka, 2007), 496.

${ }^{5}$ Agus Wibowo, 2012. Pendidikan Karakter: Strategi Membangun karakter Bangsa Berperadaban, (Yogyakarta: Pustaka Pelajar), 14

${ }^{6}$ Departemen Agama,. Al-Qur'an dan Terjemahnya,(Bandung: Diponegoro, 2006) 
"Ini adalah suatu hari yang bermanfaat bagi orang-orang yang benar kebenaran mereka. Bagi mereka surga yang di bawahnya mengalir sungai-sungai. Mereka kekeal di dalamnya selama-lamanya. Allah ridha terhadap mereka dan mereka pun ridha terhadapNya. Itulab keberuntungan yang paling besar.” (QS. al-Maidah: 119)

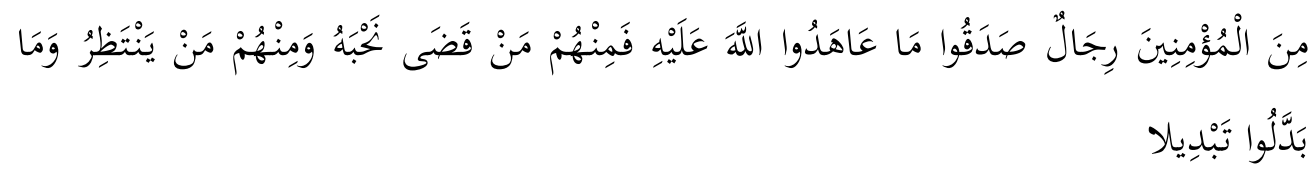

"Di antara orang-orang mukmin itu ada orang-orang yang menepati apa yang telah mereka janjikan kepada Allah. Di antara mereka ada yang gugur. Dan di antara mereka ada (pula) yang menunggu-nunggu dan mereka sedikit pun tidak merubah (janjinya).” (QS. al-Ahzab: 23)

Begitu pentingnya kejujuran ini, maka setiap anak hendaknya sudah ditanamkan sifat jujur sejak dini, terutama pada lingkungan lembaga pendidikan. Lembaga pendidikan (sekolah) memegang peran yang sangat besar dalam menanamkan nilai kejujuran pada anak didik, karena hampir separuh waktu anak berada di sekolah, mereka berinteraksi terhadap adik-adiknya, teman sebaya, bahkan dengan orang yang lebih tua (dewasa), banyak terjadi di sekolah. Oleh karena itu, guru memiliki peran yang strategis dalam menanamkan nilainilai kejujuran pada anak didiknya. Seorang guru hendaknya memiliki idealisme dan panggilan hati untuk mencintai anak didiknya, sehingga memudahkan dalam penanaman nilai-nilai kejujuran pada anak didik. Sikap ini memang tidak cukup diperoleh melalui bangku sekolah tetapi perlu dilatih dalam kehidupan keseharian. $^{7}$

\section{b. Macam-Macam Kejujuran}

Imam Al Ghazali membagi sifat jujur atau shiddiq dalam lima hal, yaitu ; jujur dalam perkataan (lisan), jujur dalam niat (berkehendak), jujur dalam kemauan, jujur dalam menepati janji, dan jujur dalam perbuatan (amaliah). ${ }^{8}$ Adapun beberapa macam kejujuran antara lain: jujur dalam niat dan kehendak, Jujur dalam ucapan, Jujur dalam tekad dan memenuhi janji, Jujur dalam

\footnotetext{
${ }^{7}$ Muhammad Amin, (2017). Peran Guru Dalam Menanamkan Nilai Kejujuran Pada Lembaga Pendidikan. TADBIR : Jurnal Studi Manajemen Pendidikan, 1(1), 105-124. doi:http://dx.doi.org/10.29240/jsmp.v1i1.222.

${ }^{8} \mathrm{Ibid}, 111$.
} 
perbuatan, Jujur dalam kedudukan agama dan jujur dalam Berikut diuraikan kelima macam kejujuran tersebut, antara lain:

1. Jujur dalam niat dan kehendak. Ini kembali kepada keikhlasan. Kalau suatu amal tercampuri dengan kepentingan dunia, maka akan merusakkan kejujuran niat, dan pelakunya bisa dikatakan sebagai pendusta, sebagaimana kisah tiga orang yang dihadapkan kepada Allah, yaitu seorang mujahid, seorang qari', dan seorang dermawan. Allah menilai ketiganya telah berdusta, bukan pada perbuatan mereka tetapi pada niat dan maksud mereka.

2. Jujur dalam ucapan. Wajib bagi seorang hamba menjaga lisannya, tidak berkata kecuali dengan benar dan jujur. Benar/jujur dalam ucapan merupakan jenis kejujuran yang paling tampak dan terang di antara macammacam kejujuran.

3. Jujur dalam tekad dan memenuhi janji. Contohnya seperti ucapan seseorang, "Jikalau Allah memberikan kepadaku harta, aku akan membelanjakan semuanya di jalan Allah." Maka yang seperti ini adalah tekad. Terkadang benar tetapi adakalanya juga ragu-ragu atau dusta. Hal ini sebagaimana firman Allah:

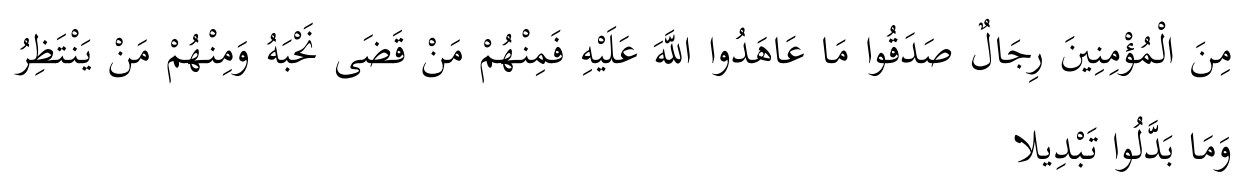

"Di antara orang-orang mukmin itu ada orang-orang yang menepati apa yang telah mereka janjikan kepada Allah; maka di antara mereka ada yang gugur. Dan di antara mereka ada (pula) yang menunggu-nunggu dan mereka sedikit pun tidak. merubah (janjinya)." (QS. al-Ahzab: 23)

4. Jujur dalam perbuatan, yaitu seimbang antara lahiriah dan batin, hingga tidaklah berbeda antara amal lahir dengan amal batin, sebagaimana dikatakan oleh Mutharrif, "Jika sama antara batin seorang hamba dengan lahiriahnya, maka Allah akan berfirman, 'Inilah hambaku yang benar/jujur."

5. Jujur dalam kedudukan agama. Ini adalah kedudukan yang paling tinggi, sebagaimana jujur dalam rasa takut dan pengharapan, dalam rasa cinta dan

\footnotetext{
${ }^{9}$ Departemen Agama, Op.Cit.
} 
tawakkal. Perkara-perkara ini mempunyai landasan yang kuat, dan akan tampak kalau dipahami hakikat dan tujuannya. Kalau seseorang menjadi sempurna dengan kejujurannya maka akan dikatakan orang ini adalah benar dan jujur, sebagaimana firman Allah,

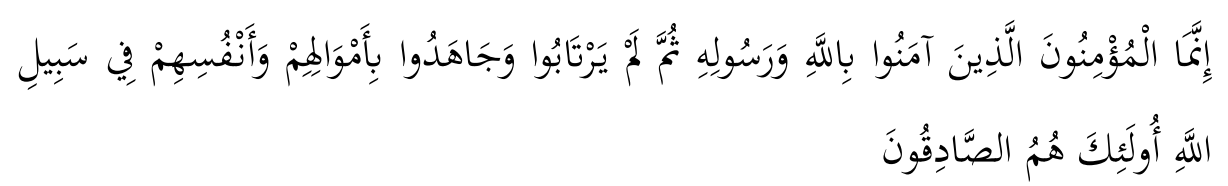

Artinya: "Sesunggubnya orang-orang yang beriman hanyalah orang-orang yang beriman kepada Allab dan Rasul-Nya kemudian mereka tidak ragu-ragu dan mereka berïhad dengan harta dan jiwa mereka pada jalan Allah, mereka itulah orang-orang yang benar." (QS. al-Hujurat: 15) ${ }^{10}$

6. Jujur dalam akademik, kejujuran akademik adalah suatu perilaku dalam lingkup akademik yang dilakukan dengan mengedepankan kebenaran atau kenyataan yang ada, tidak berbuat curang atau berbohong, berkata yang sebenarnya, tidak menyembunyikan suatu informasi apapun, serta bertindak sesuai dengan peraturan yang ditetapkan di lingkungan sekolah. ${ }^{11}$

Realisasi perkara-perkara ini membutuhkan kerja keras. Tidak mungkin seseorang manggapai kedudukan ini hingga dia memahami hakikatnya secara sempurna. Setiap kedudukan (kondisi) mempunyai keadaannya sendiri-sendiri. Ada kalanya lemah, ada kalanya pula menjadi kuat. Pada waktu kuat, maka dikatakan sebagai seorang yang jujur. Dan jujur pada setiap kedudukan (kondisi) sangatlah berat. Terkadang pada kondisi tertentu dia jujur, tetapi di tempat lainnya sebaliknya. Salah satu tanda kejujuran adalah menyembunyikan ketaatan dan kesusahan, dan tidak senang orang lain mengetahuinya.

\section{c. Implikasi Kejujuran dalam kehidupan}

Orang yang selalu berbuat kebenaran dan kejujuran, niscaya ucapan, perbuatan, dan keadaannya selalu menunjukkan hal tersebut. Allah telah memerintahkan Nabi untuk memohon kepada-Nya agar menjadikan setiap langkahnya berada di atas kebenaran sebagaimana firman Allah:

\footnotetext{
${ }^{10}$ Departemen Agama, Ibid.

${ }^{11}$ Erlisia Ungusari, Op.Cit, 3
} 


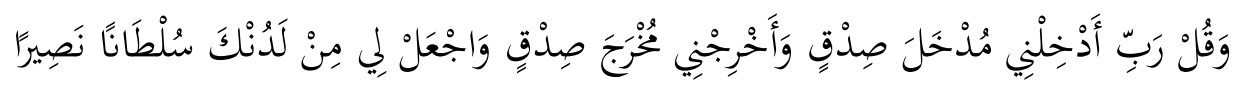

"Dan katakanlah (wahai Mubammad), Ya Tuban-ku, masukkanlah aku secara masuk yang benar dan keluarkanlah (pula) aku secara keluar yang benar dan berikanlah kepadaku dari sisi-Mu kekuasaan yang menolong.” (QS. al-Isra': 80)

Allah juga mengabarkan tentang Nabi Ibrahim yang memohon kepada-Nya untuk dijadikan buah tutur yang baik.

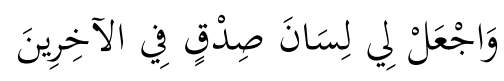

"Dan jadikanlah aku buah tutur yang baik bagi orang-orang (yang datang) kemudian." (QS. asy-Syu'ara': 84)

Hakikat kejujuran dalam hal ini adalah hak yang telah tertetapkan, dan terhubung kepada Allah. Ia akan sampai kepada-Nya, sehingga balasannya akan didapatkan di dunia dan akhirat. Allah telah menjelaskan tentang orang-orang yang berbuat kebajikan, dan memuji mereka atas apa yang telah diperbuat, baik berupa keimanan, sedekah ataupun kesabaran. Bahwa mereka itu adalah orangorang jujur dan benar, Allah berfirman:

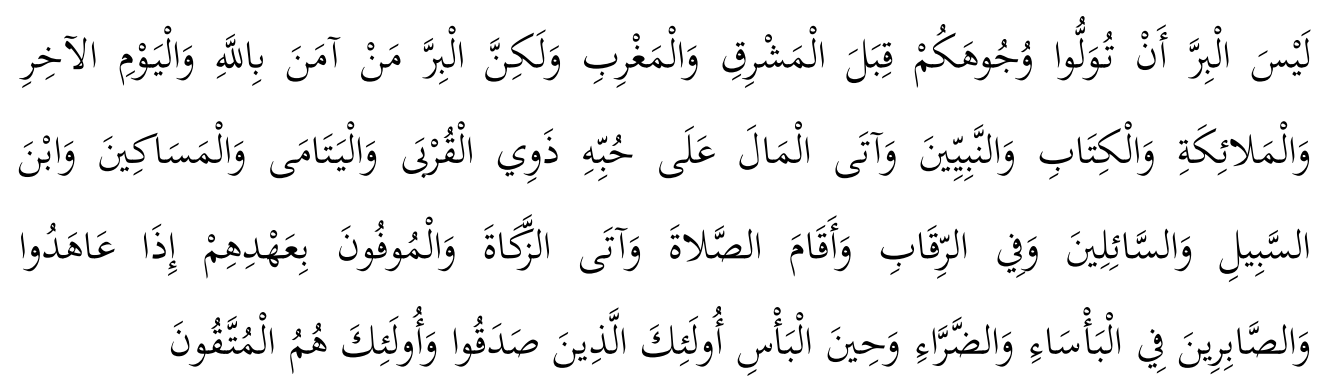

"Bukanlah menghadapkan wajahmu ke arah timur dan barat itu suatu kebajikan, akan tetapi sesungguhnya kebajikan itu ialah beriman kepada Allah, hari kemudian, malaikat-malaikat, kitab-kitab, nabi-nabi dan memberikan harta yang dicintai kepada karib kerabat, anak-anak yatim, orang-orang miskin, musafir yang memerlukan pertolongan) dan orang-orang yang meminta-minta; dan (memerdekakan) hamba sabaya, mendirikan shalat, dan menunaikan zakat; dan orang-orang yang menepati janjinya apabila dia berjanji, dan orang-orang yang sabar dalam kesempitan, penderitaan dan dalam 
peperangan. Mereka itulah orang-orang yang benar (imannya); dan mereka itulah orangorang yang bertakwa.” (QS. al-Baqarah: 177)

Di sini dijelaskan dengan terang bahwa kebenaran itu tampak dalam amal lahiriah dan ini merupakan kedudukan dalam Islam dan Iman. Kejujuran serta keikhlasan keduanya merupakan realisasi dari keislaman dan keamanan. Orang yang menampakkan keislaman pada dhahir (penampilannya) terbagi menjadi dua: mukmin (orang yang beriman) dan munafik (orang munafik). Yang membedakan diantara keduanya adalah kejujuran dan kebenaran atas keyakinannya. Oleh sebab itu, Allah menyebut hakekat keimanan dan mensifatinya dengan kebenaran dan kejujuran, sebagaimana firman Allah,

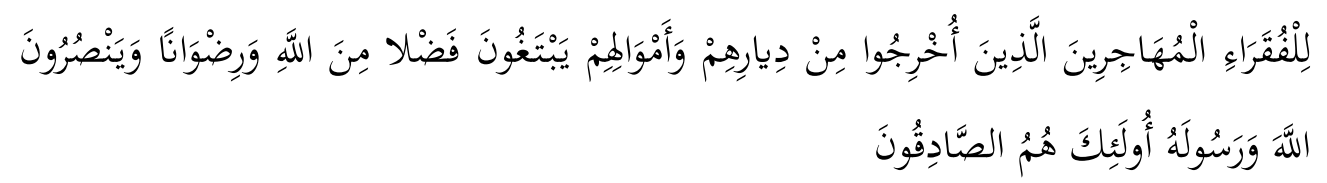

"(Juga) bagi para fuqara yang berbijrah yang diusir dari kampung halaman dan dari harta benda mereka (karena) mencari karunia dari Allah dan keridhaan (Nya) dan mereka menolong Allab dan Rasul-Nya. Mereka itulah orang-orang yang benar." (QS. alHasyr: 8$)^{12}$

\section{Upaya Guru Menanmkan Nilai Kejujuran}

Sebelum membahas upaya guru pendidikan agama Islam menanamkan nilai-nilai keagamaan (kejujuran) terlebih dahulu dibahas makna nilai dalam perspektif kehidupan sosial. Secara harfiah kata nilai mengandung makna sebagai sesuatu yang diyakini kebenarannya dan dianut serta dijadikan sebagai acuan dasar individu dan masyarakat dalam menentukan sesuatu yang dipandang baik, benar, bernilai maupun berharga. Menurut John W. Berry disebutkan bahwa "nilai menujukkan pada suatu konsep yang dimiliki dan digunakan individu atau suatu anggota kelompok secara kolektif mengenai sesuatu yang diharapkan (desirable) dan berpengaruh terhadap pemilihan cara maupun tujuan tindakan dari beberapa alternatif'. ${ }^{13}$ Nilai merupakan daya pendorong dalam hidup yang memberikan makna dan pengabsahan pada

\footnotetext{
12 Departemen Agama, Op.Cit.

13 John W. Berry, dkk.. Psikologi Lintas-Budaya Riset dan Aplikasi. (Jakarta: Gramedia Pustaka Utama, 1999), 102.
} 
tindakan seseorang. ${ }^{14}$ Berdasarkan pernyataan ini menunjukkan bahwa nilai menjadi penting dalam kehidupan seseorang sehingga tidak jarang pada tingkat tertentu orang siap mengorbankan hidup mereka demi mempertahankan nilai.

Williams Macionis mengemukakan bahwa nilai merupakan: “...what is desirable, good or bad, beautiful or ugly. ${ }^{15}$ Sedang Light, Kelle memberikan batasan nilai sebagai berikut: "Value is general idea that people share about what is good or bad, desirable or undesirable. Value transcend any one particular situation. ...V Value people bold tend to color their overall way of life". ${ }^{16}$ (Nilai merupakan gagasan umum orangorang, yang berbicara seputar apa yang baik atau buruk, yang diharapkan atau yang tidak diharapkan. Nilai mewarnai pikiran seseorang dalam situasi tertentu . .... Nilai yang dianut cenderung mewarnai keseluruhan cara hidup mereka). Nilai bukan saja dijadikan rujukan untuk bersikap dan berbuat dalam masyarakat, akan tetapi dijadikan pula sebagai ukuran benar tidaknya suatu fenomena perbuatan dalam masyarakat itu sendiri. Apabila ada suatu fenomena sosial yang bertentangan dengan sistem nilai yang dianut oleh masyarakat, maka perbuatan tersebut dinyatakan bertentangan dengan sistem nilai yang dianut oleh masyarakat, dan akan mendapatkan penolakan dari masyarakat tersebut. Sedangkan kejujuran, berasal dari kata jujur artinya lurus hati, tidak berbohong, tidak curang (misal dalam permainan, evaluasi, kompetensi, dan lain-lain). ${ }^{17}$

Menurut Muhaimin dkk pendidikan agama Islam di sekolah akan berhasil dengan optimal dalam memberi "makna" dan "warna" serta menanamkan nilai-nilai fundamental bagi pembentukan sikap peserta didik kalau dibarengi dengan sikap proaktif dari guru agama serta adanya keterpaduan pembinaan. Sikap proaktif yang dimaksud adalah bahwa seseorang mampu keluar dari srtuktur, kondisi, dan aturan yang ada, untuk berusaha mencari jalan baru atau berada dalam perspektif "mengubah" sesuai dengan konteksnya: ${ }^{18}$ Ada beberapa pendekatan penanaman nilai yang dapat digunakan guru dalam proses pembelajaran, antara lain yaitu pendekatan: pengalaman, pembiasaan,

33.

${ }^{14}$ Jalaluddin.. Teologi Islam: Interpretasi Untuk Aksi. (Bandung : Mizan, 1996), 227.

${ }^{15}$ Macionis, J. J.. Society the Basics. (New Jersey: Prentice Hall, Englewood Cliffs, 1970),

${ }^{16}$ Light, D., Keller, S., \& Calhoun, C.. Sociology.( New York: Alfred A. Knopf, 1989),

81

${ }^{17}$ Tim Penyusun Kamus Departemen Pendidikan Dan Kebudayaan. Kamus Besar Bahasa Indonesia. (Jakarta Balai Pustaka, 1995), 479.

${ }_{18}$ Muhaimin. Paradigma Pendidikan Islam Upaya Mengefektifkan Pendidikan Agama Islam Di Sekolah.(Bandung: Remaja Rosdakarya, 2002), 110 
emosional, rasional, fungsional, dan keteladanan. ${ }^{19}$ Fuad Ihsan menambahkan beberapa cara mentranformasi dan menginternalisasikan nilai-nilai agama pada peserta didik melalui pergaulan yang baik antara pendidik dan peserta didik, memberi suri tauladan yang baik dan mengajak untuk mengamalkan nilai-nilai luhur Islam dalam kehidupan sehari-hari. ${ }^{20}$

Berikut contoh penanaman nilai-nilai karakter bangsa melalui mata pelajaran pendidikan agama Islam di SMA Negeri, yaitu : Pertama, secara konteks penanaman nilai-nilai, karakter bangsa pada mata pelajaran, pendidikan Agama Islam pada peserta didik dapat berhasil dengan adanya iklim dan sistem yang mendukung seperti kebijakan kepala sekolah. Kedua, aspek input yakni sumber daya sekolah yang berkualitas meliputi kepala sekolah, tenaga pendidik dan kependidikan, peserta didik, dan sarana prasarana sekolah sangat mendukung upaya penanaman dan pengembangan nilai-nilai karakter bangsa di kedua sekolah SMA. Ketiga, proses penanaman nilai-nilai karakter bangsa pada mata pelajaran Pendidikan Agama Islam dilaksanakan melalui pembelajaran intrakurikuler, ekstrakurikuler. ${ }^{21}$

Beberapa contoh penanaman nilai kejujuran, diantaranya yaitu penanaman nilai nilai kejujuran di asrama MAN 3 Palembang terdiri dari beberapa kegiatan pembinaan antara lain adalah (a) kegiatan pembinaan keimanan dan ketakwaan kepada Tuhan Yang Maha Esa, (b) penegakan disiplin dan tata tertib asrama MAN 3 Palembang. Pembinaan nilai nilai kejujuran tersebut diimplementasikan melalui beberapa strategi dan pendekatan seperti berikut: (a) pengintegrasian nilai nilai kejujuran dan etika pada kegiatan asrama, (b) internalisasi nilai nilai kejujuran yang ditanamkan oleh semua warga asrama (siswi, mentor), (c) pembiasaan dan latihan, (d) pemberian contoh dan teladan, (e) menciptaan suasana berkarakter di asrama, dan (f) pembudayaan kejujuran di asrama. ${ }^{22}$

Dapat dipahami bahwa Guru dapat menerapkan nilai kejujuran di sekolah baik pada kehidupan sehari-hari maupun saat evaluasi belajar dengan

\footnotetext{
${ }^{19}$ Ramayulis..Ilmu pendidikan Islam.( Jakarta: Kalam Mulia, 2004), 41-42.

${ }^{20}$ Fuad Ihsan, Dasar-Dasar Kependidikan.(Jakarta: Rineka Cipta, 1997), 155-156.

${ }^{21}$ Yustiani, Penanaman Nilai-Nilai Karakter Bangsa Melalui Mata Pelajaran Pendidikan Agama Islam di SMA Negeri, Analisa Journal of Social Science and Religion Volume 22 No. 01 June 2015, 135-147.
}

${ }^{22}$ Messi dan Edi Harapan, Menanamkan Nilai Nilai Kejujuran di dalam Kegiatan Madrasah Berasrama (Boarding School), JMKSP Jurnal Manajemen, Kepemimpinan, dan Supervisi Pendidikan, Volume 1, No. 1, Juli-Desember 2017. 
berbagai cara antara lain: (a) menjelaskan pada siswa hakikat evaluasi, (b) membentuk strategi soal dengan cara membuat paket soal. (c) bersikap jujur di hadapan siswa, (d) sikap kritis dan perhatian yang mendalam terhadap tugas siswa, (e) konsep kantin kejujuran, (f) konsep polisi moral.

\section{Metodologi Penelitian}

Penelitian ini termasuk penelitian lapangan (field research) yaitu penelitian dengan cara langsung ke tempat penelitian untuk mengamati dan terlibat langsung dengan objek penelitiannya. Jenis penelitiannya ialah penelitian studi kasus yang bersifat kualitatif dengan logika berfikir induktif, dimana penelitian ini memiliki karakteristik bahwa datanya dinyatakan dalam keadaan sewajarnya. Jenis data yang digunakan dalam penelitian ini merupakan data primer dan data sekunder. Data primer merupakan data yang peneliti dapatkan dengan menggunakan observasi, dokumentasi, dan wawancara, atau data-data yang diperoleh langsung dari informen seperti kepala sekolah, wakil kepala sekolah bidang kesiswaan, guru agama pendidikan Islam, guru Bimbingan Konseling. Dan data sekunder merupakan data pendukung yang sudah berbentuk, seperti buku-buku ilmiah, dokumen dan peraturan-peraturan yang berkaitan dengan penelitan yang dilakukan. Untuk memperoleh data dalam penelitian ini, peneliti menggunakan beberapa metode dalam pengumpulan data agar memperoleh data yang valid yaitu observasi, wawancara dan dokumentasi. Teknik analisis data yang digunakan adalah teknik deskriptif. Sebagaimana yang dikemukakan oleh Sugiyono bahwa analisis data deskriptif dilakukan dengan tiga cara, yaitu: Reduksi data, Display data, Penarikan kesimpulan dan verifikasi data $^{23}$

\section{Hasil Penelitian}

Berdasarkan wawancara dengan guru pendidikan agama Islam, salah satunya bapak Alfian di SMK Nurul Iman Palembang, beliau mengemukakan Ujian Nasional adalah salah satu kebijakan pemerintah yang diselenggarakan pada setiap tahun, dimana siswa yang mengikuti Ujian Nasional tersebut adalah siswa yang duduk di bangku akhir sekolah, misal pada tingkat sekolah dasar yang boleh mengikuti Ujian Nasional adalah siswa yang duduk di kelas enam, pada tingkat sekolah menengah pertama adalah siswa yang duduk di kelas sembilan dan pada tingkat sekolah menengah atas dan kejuruan adalah siswa

\footnotetext{
${ }^{23}$ Sugoyono, Metodologi Penelitian Pendidikan, (Bandung:Alfabeta, 2015), 345.
} 
kelas dua belas. Adapun penanaman nilai kejujuran saat Ujian Nasional di SMK Nurul Iman Palembang antara lain:

\section{Menghimbau dan Menasehati Siswa}

Para guru, tidak hanya guru pendidikan agama Islam melainkan semua guru menghimbau dan menasehati siswa untuk rajin belajar baik di rumah maupun di sekolah serta memanfaatkan waktu belajar dengan sebaik-baiknya karena siswa yang rajin belajar misal mengulas kembali pelajaran yang telah disampaikan dengan begitu ketika ulangan siswa tidak perlu lagi mempelajari materi tersebut dengan sistem belajar kebut semalam sebab siswa telah menguasai materi tersebut, selain bekal persiapan ulangan atau evaluasi bisa juga dijadikan bekal siswa di kemudian hari. Menjelaskan pada siswa pentingnya mengatur waktu sebaik-baiknya, misal memperhatikan penjelasan guru di kelas, menanyakan materi-materi yang belum dipahami, mengembangkan pengetahuan yang telah di dapat dan mencari informasi baru tentang materi yang diajarkan dengan menggunakan media IT, buku-buku penunjang atau buku-buku yang berkaitan dengan mata pelajaran.

\section{Mengadakan Evaluasi Dadakan}

Kegiatan evaluasi dadakan ini diadakan guru dengan cara tiba-tiba tanpa memberi tahu siswa terlebih dahulu, hal ini dilakukan untuk mengetahui atau mengukur kemampuan siswa memahami materi yang telah disampaikan dan mengulas kembali ingatan siswa terhadap materi yang diajarkan baik pada materi baru maupun materi awal pembelajaran. Selain itu evaluasi dadakan ini di adakan agar siswa selalu mempersiapkan diri dengan memperbanyak waktu belajar dan memotivasi siswa untuk benar-benar memahami materi pelajaran.

\section{Memupuk Keimanan kepada Allah Swt}

Semua siswa diajak untuk selalu mengingat Allah dimanapun berada sehingga takut untuk melakukan dosa atau kekeliruan dengan sengaja sekalipun tidak diketahui orang lain. Jika siswa percaya Allah memiliki sifat maha mengetahui maka siswa akan melakukan segala perbuatan dengan hati-hati dan menimang terlebih dahulu baik atau buruk perbuatan tersebut. Begitu juga ketika Ujian Nasional berlangsung, siswa yakin bahwa Allah berada dimanamana, maha melihat dan maha mengetahui sehingga siswa menghindari kecurangan, menyontek, meminta jawaban dengan teman lain sekalipun tidak terlihat oleh guru ataupun pengawas pada saat Ujian. Sekolah harus 
menanamkan nilai-nilai keTuhanan, kesalehan, kewarganegaraan sebagi sumber perilaku. Sumber perilaku tersebutakan diinternalisasi melalui proses pendidikan karakter dengan memahami, peduli dan mengimplementasikan nilai-nilai tersebut dalam kehidupan sehari-hari baik di rumah, sekolah maupun masyarakat. Proses pembentukan karakter seperti yang harus terus menerus dilakukan sehingga menghasilkan perilaku berkarakter pada anak, oleh karena itu untuk membentuk karakter anak yang baik dan positif, diperlukan sinergi yang harmonis antara proses pembelajaran di kelas yang memberntuk aspek otonomi anak dengan budaya dan lingkungan sekolah sebagi aspek heteronomi harus berjalan dan saling mendukung, ketika salah satunya rapuh bahkan saling bertentangan maka pembentukan karakter anak tidak akan berjalan baik dan efektif termasuk mungkin akan tergusurnya karakter kejujuran.

\section{Menjelaskan Manfaat Jujur saat Ujian Nasional}

Jujur adalah bibit unggul. Percuma baik tetapi tidak unggul dia bisa dipanen dan dikonsumsi, tetapi kalau tidak unggul dia hanya mandeg sampai dikonsumsi saja. Tetapi kalau unggul dia masih bisa dijadikan bibit lagi untuk menghasilkan butiran-butiran padi yang lain. Karenanya jangan gadaikan Ujian Nasional dengan sikap tidak jujur. Nilai kejujuran bisa dinilai dari pemahaman pada setiap diri yang tersangkut dalam Ujian Nasional. UN bukan hanya urusan kelulusan tapi media membangun karakter. Mengingat bahwa siswa merupakan calon agen pembaharu (agent of change) yang akan berperan membawa perubahan-perubahan konstruktif bagi negeri ini, hendaknya makna pendidikan jangan menyempit, hanya dinilai dengan angka. Namun pendidikan penting melihat aspek secara keseluruhan. Karena kejujuran dalam bertindak sangatlah diperlukan. Terlebih lagi kejujuran dalam pelaksanaan Ujian Nasional. Karena kejujuran yang didapatkan oleh generasi bangsa ini sangat mempengaruhi kondisi bangsa ke depan. Pendidikan seharusnya membangun fondasi moral bangsa. Kalau dalam Ujian Nasional terdapat kebohongan hal itu justru akan menjadi bomerang. Kualitas pendidikan dan lulusan akan menjadi taruhan. Karena hasil itu adalah semu dan rekayasa, inilah hasil Pendidikan Karakter yang di tanamkan disekolah akan dipertaruhkan dalam Kejujuran Ujian Nasional mendatang. Akhirnya, jangan kotori Ujian Nasional dengan sikap tidak jujur. Jangan nodai pendidikan Indonesia dengan sikap tidak jujur. Kejujuran Ujian nasional adalah investasi yang mahal untuk mencetak generasi bangsa yang bermartabat. Sedikit saja dimasuki "kotoran" maka kualitasnya akan tercemar. Kejujuran perlu dijaga kemurnian dan dilestarikan selamanya terutama 
dalam Ujian Nasional. Bagaimana mau memberantas korupsi kalau kecurangan di awali dari masa pendidikan di Sekolah. Mari para pendidikan, teman teman guru, kita meneladani Sosok Rasulullah Muhammad SAW sebagai Guru Peradaban Dunia dalam menyikapi Ujian Nasional mendatang.

Jadi dapat disimpulkan penanaman nilai kejujuran saat Ujian Nasional di SMK Nurul Iman Palembang pada point menghimbau dan menasehati siswa, memupuk keimanan kepada Allah Swt, menjelaskan manfaat jujur saat ujian nasional. Hal ini selaras dengan pendapat yang dikemukakan Yustiani bahwa penanaman nilai-nilai, karakter bangsa pada mata pelajaran, pendidikan Agama Islam pada peserta didik dapat berhasil dengan adanya iklim dan sistem yang mendukung seperti kebijakan kepala sekolah ${ }^{24}$.

Pembinaan nilai nilai kejujuran pada ujian nasional berdasarkan pendapat Messi dan Edi Harapan ${ }^{25}$ dapat diimplementasikan melalui beberapa strategi dan pendekatan seperti berikut: (a) pengintegrasian nilai nilai kejujuran dan etika saat ujian Nasional (b) internalisasi nilai nilai kejujuran yang ditanamkan oleh semua tenaga pendidikan kepada peserta didik (c) pembiasaan dan latihan untuk bersikap jujur (d) pemberian contoh dan teladan nilai kejujuran oleh tenaga pendidik dan peserta didik (e) menciptaan suasana jujur di sekolah (f) pembudayaan kejujuran di sekolah.

Puncak dari kejujuran akademik adalah ketika ujian nasional. Pada saat itulah kepala sekolah, guru, dan siswa akan diuji kejujurannya. Apakah hanya demi mendapat murid dan mendapat sanjungan sebagai kepala sekolah yang berhasil, seorang kepala sekolah menginstruksikan semua guru untuk memberi kunci jawaban kepada siswa? Apakah hanya karena merasa kasihan kepada siswa seorang guru rela berbuat tidak jujur dengan memberi kunci jawaban? Apakah hanya karena ingin lulus ujian nasional dengan nilai tinggi, seorang siswa berani menyontek temannya atau menggunakan kunci jawaban dari guru? Kejujuran itu memang terkadang pahit tetapi kepahitan itu harus kita terima karena kita adalah umat beragama yang patuh pada perintah Tuhan. Sebagai umat beragama, kita harus berpikir jauh ke depan, tidak hanya berpikir untuk urusan dunia saja tetapi harus berpikir juga untuk kehidupan akhirat. Akan ada begitu banyak rintangan dan hambatan yang kita temui dalam menerapkan kejujuran. Oleh karena itu, kita harus tetap konsisten untuk bersikap jujur dalam kehidupan ini. Terlebih lagi bagi seorang guru. Dia harus menerapkan kejujuran

\footnotetext{
${ }^{24}$ Yustiani,Op.Cit, 135-147.

${ }^{25}$ Messi dan Edi Harapan, Op.Cit
} 
dalam segala aspek kehidupan. Dia harus menjadi teladan bagi teman sejawat dan murid-muridnya. Jika semua dapat menerapkan kejujuran, insya Allah tidak akan ada lagi koruptor di negara ini.

\section{Faktor Pendukung Penanaman Nilai-nilai Akhlakul Karima saat Ujian Nasional}

Segala sesuatu bisa diciptakan atau ditumbuhkan tentu memiliki maksud, tujuan dan sebab tertentu. Adapun faktor pendukung sekolah menanamkan nilai-nilai akhlakul karima saat ujian nasional antara lain:

\section{Diadakannya tadarus Al-Qur'an}

Selama lima belas menit sebelum memulai pelajaran pertama atau sebelum memulai kegiatan proses belajar mengajar yang dipandu langsung oleh guru yang bertugas dari kantor sekolah serta diawasi oleh guru piket dan dibantu guru yang mengajar pada mata pelajaran pertama, hal inii dilakasanaka dengan tujuan agar siswa-siswi SMK Nurul Iman Palembang mampu membaca Al-Qur'an dan selalu mengingat Allah SWT, selain itu juga SMK Nurul Iman Palembang berharap siswa-siswinya tidak hanya memiliki kemampuan skil saja tetapi diimbangi dengan kepribadian yang baik, memiliki akhlakul karimah.

\section{Siswa Selalu diberikan Siraman Rohani}

Pemberian siraman rohani tentang sikap dan sopan santun dalam kehidupan sehari-hari, baik guru ketika mengajar di kelas, dengan diadakannya ceramah bulanan di masjid Nurul Iman Palembang pada setiap bulannya, pengadaan majlis taklim wanita pada hari jum'at khusus untuk siswi ketika para siswa melakukan salat jum'at berjam'ah, mewajibkan siswa salat zuhur berjama'ah secara bergilir untuk kelas yang telah ditentukan. Karakter yang dibangun secara konseptual dengan menggunakan pilar moral dengan melalui dua aspek yang saling terkait yakni aspek otonomi dan heteromoni, aspek otonomi merujuk pada proses pembelajaran melalui internalisasi dalam diri anak yang ditujukan melalui kemampuan melakukan orientasi evaluatif dimana siswa dapat membedakan baik dan buruk serta mengatur yang baik dan menghindari yang buruk, memiliki kewajiban terhadap standar sosial kolektif, memiliki tanggung jawab untuk peduli terhdapa orang lain, memiliki perhatian akan hakhak orang lain, memiliki komitmen kejujuran dalam hubungan interpersonal serta memiliki keadaan pikiran yang menyebabkan reaksi emosi negatif terhadap tindakan amoral. Sementara heteromoni merujuk pada aspek eksternal yang 
berada diluar diri anak yakni adanya penegakan peraturan sekolah, keteladan para guru dan pimpinan sekolah, perilaku yang adil bagi setiap siswa, keteladanan para guru dan pimpinan sekolah, perilaku yang adil bagi setiap siswa, lingkungan sekolah yang menyenangkan dan mengembangkan potensi siswa.

\section{Dilakukan pengawasan intensif}

Pengawasan intensif dilakukan saat ulangan, evaluasi belajar, ujian nasional berlangsung, dengan cara guru mengawasi siswa-siswa dengan cara berkeliling kelas, memeriksa siswa-siswi satu persatu, melihat gerak gerik siswa saat ulangan, evaluasi, ujian nasional berlangsung dan menegur siswa-siswi yang mencurikan, melakukan keributan atau gaduh di kelas dan memberikan sangsi bagi siswa-siswi yang melakukan pelanggaran, Pengawas ruang yang baik dan tertib akan turut memberikan makna yang berarti dalam kelancaran pelaksanaan Ujian Nasional. Pengawas ruang Ujian Nasional sewaktu mengawasi semestinya bertindak sewajarnya dan bukan bertindak berlebihan, bersikap yang menakutkan yang justru akan berdampak negatif terhadap mental dan psikis peserta ujian. Selain itu juga harus berani bersikap yang tegas, diantaranya melarang siapapun yang akan masuk ruang ujian selain peserta ujian. hal ini dilakukan supaya siswa-siswi SMK Nurul Iman Palembang selalu terbiasa mempersiapkan diri terhadap mata pelajaran yang dipelajari dengan cara belajar, memahami materi yang telah disampaikan, memperhatikan penjelasan guru di kelas dan tidak lengah saat belajar .

\section{Dilarang Membawa Benda selain Peralatan Ujian Nasional}

Siswa tidak diperkenankan membawa benda apapun kecuali perlatan ujian nasional yaitu pensil, pulpen, papan alas ujian, penggaris LJK, penghapus pensil. Hal ini dilakukan untuk mengantisipasi bagi siswa-siswi yang malakukan kecurangan saat ujian nasional berlangsung dengan cara menggunakan alat elektronik (Hand Phone), membuat contekan di lembaran kertas lain, dan berbagai macam cara lainnya.

\section{Dilarang Bermusyawarah saat Ujian Nasional}

Siswa tidak diperkenankan bermusyawarah dengan teman yang lain selama ujian nasional berlangsung dalam hal apapun baik menanyakan masalah soal ujian nasional, meminjam alat tulis apalagi meminta jawaban kepada siswa 
yang lain, siswa-siswi diharapan selalu dalam keadaan tenang tanpa membuat keributan di ruang ujian saat ujian nasional berlangsung.

\section{Dibacakan Ikrar Ujian Nasional Jujur dan Berprestasi di Depan Kelas}

Secara substansi, tidak ada perbedaan mengenai pelaksanaan Ujian Nasional (UN) sekolah pada tahun ini dengan tahun lalu. Hanya saja, pemerintah mencoba menerapkan semacam komitmen agar semua pihak berupaya melaksanakan UN dengan jujur, transparan dan tanpa kecurangan. Kejujuran saat Ujian Nasional harus ditanamkan merujuk hakikat Ujian Nasional yaitu sebagai alat ukur untuk mengetahui tingkat kemampuan, prestasi siswa pada proses pembelajaran, dari sisi perserta Ujian siswa juga seharusnya lebih percaya diri terhadap kemampuan mereka, jika menginginkan nilai baik maka setiap siswa dituntut untuk lebih giat dalam belajar, dengan adanya kepercayaan diri tawaran bocoran soal tidak akan menggoyahkan pendirian para siswa kemudia penegasan kembali oleh guru dan kepala sekolah tentang hakikat dan tujuan diselenggarakan ujian nasional juga sangat penting yaitu untuk mengukur sejauh mana kemampuan akademik peserta didik, sehingga memberikan kunci jawaban kepada peserta didik bukanlah cara mendidik bahkan akan menjerumuskan siswa dalam kebodohan dengan menanamkan nilai kejujuran kepada siswa dan para guru dalam mengikuti Ujian Nasional diharapkan rangkaian Ujian Nasional yang mendatang tidakl lagi diwarnai kecurangan apalagi mencotak masal. Apalah arti nilai baik jika didapat dari kecurangan dan alangkah bahagianya jika nilai baik itu hasil dari usaha dan jerih payah sendiri, jika semua prosedur dapat dilaksanakan dengan sungguh-sungguh maka kecurangan dalam Ujian Nasional tidak akan terulang kembali pada tahuntahun yang akan datang.

Dari beberapa upaya sekolah menanamkan akhlakuk karimah saat ujian nasional berlangsung belum mendapatkan dukungan sepenuhnya oleh berbagai pihak yang berada pada SMK Nurul Iman Palembang, berdasarkan observasi di lapangan masih ada kecurangan yang dilakukan oleh beberapa guru. Guru memberikan beberapa terik kepada siswa untuk mengalihkan perhatian pengawas saat ujian nasional antara lain dengan meminta siswa menyediakan makanan, minuman serta surat kabar harian (koran) sebagai bahan bacaan saat ujian nasional berlangsung, selain itu guru menghimbau kepada para siswa untuk mengeluarkan bangku yang ada di sebelah mereka hal ini di upayakan agar pengawas tidak duduk di samping siswa dan mengawasi secara intensif saat 
pelaksanaan ujian nasional, bahkan ada seorang guru yang memberikan terik menyontek saat ujian nasional berlangsung dengan cara memberikan kode-kode pada sesama teman ketika meminta jawaban pada siswa agar proses percontekkan tidak terlalu transparan. Selain itu juga ada kecurangan lain yang dilakukan pihak sekolah dengan mengultimatum para wali kelas dan guru mata pelajaran agar tidak memberikan nilai raport siswa mulai dari semester satu (kelas XI ) dibawah KKM terutama pada mata pelajaran yang akan masuk pada ujian nasional.

\section{Kesimpulan}

Upaya sekolah menanamankan kejujuran saat Ujian Nasional di SMK Nurul Iman Palembang antara lain: Pertama, menghimbau dan menasehati siswa untuk rajin belajar baik di rumah maupun di sekolah serta memanfaatkan waktu belajar dengan sebaik-baiknya. Kedua, mengadakan evaluasi dadakan. Ketiga, memupuk iman kepada Allah mengakui bahwa tiada Tuhan selain Allah, selalu mengingat Allah dimanapun berada sehingga takut untuk melakukan dosa atau kekeliruan dengan sengaja sekalipun tidak diketahui orang lain. Keempat, menjelaskan manfaat jujur saat Ujian Nasional.

Faktor pendukung sekolah menanamkan akhlakul karimah (nilai-nilai kejujuran) saat Ujian Nasional antara lain: Pertama, diadakannya tadarus AlQur'an (pembacaan surat yasin) selama lima belas menit sebelum memulai pelajaran pertama yang dipandu langsung oleh guru yang bertugas dari kantor dan diawasi oleh guru piket serta dibantu oleh guru yang mengajar pada jam pelajaran pertama. Kedua, siswa selalu diberikan siraman rohani tentang sikap dan sopan santun dalam kehidupan sehari-hari, baik guru ketika mengajar di kelas, dengan diadakannya ceramah bulanan di masjid Nurul Iman Palembang pada setiap bulannya, pengadaan majlis taklim wanita pada hari jum'at khusus untuk siswi ketika para siswa melakukan salat jum'at berjam'ah, mewajibkan siswa salat zuhur berjama'ah secara bergilir untuk kelas yang telah ditentukan. Ketiga, melakukan pengawasan intensif saat Ujian Nasional berlangsung, siswa tidak diperkenankan membawa benda apapun kecuali peralatan Ujian Nasional yaitu pensil, pulpen, papan alas ujian, penggaris LJK, penghapus pensil. Siswa tidak diperkenankan bermusyawarah dengan teman yang lain selama ujian nasional berlangsung. 


\section{Bibliografi}

Abdurrahmansyah. 2005. Pendidikan Islam Khazanah Filosofis Dan Implementasi Kurikulum, Metodologi dan Tantangan Pendidikan Moralitas. Yogyakarta: Global Pustaka Utama.

Al-Qardhawi, Yusuf. 1980. Pendidikan Islam dan Madrasah Hasan Al-Bann., terj. Prof. H. Bustami A. Gani dan Drs.Zainal Abidin Ahmad. Jakarta: Bulan Bintang.

Amin, M. (2017). Peran Guru Dalam Menanamkan Nilai Kejujuran Pada Lembaga Pendidikan. TADBIR : Jurnal Studi Manajemen Pendidikan, 1(1), 105-124. doi:http://dx.doi.org/10.29240/jsmp.v1i1.222.

Ancok, Djamaluddin, Fuad Nashori Suroso. 1999. Psikologi Islami: Solusi Islam Atas Problem-Problem Psikologi. Yogyakarta: Pustaka Pelajar.

Al-syaibani, Omar Muhammad Al-Toumy. 1975. Falsafah Pendidika Islam. Abli Bahasa Hasan langgulung. Jakarta: Bulan Bintang.

Arifin, M. 2010. Ilmu Pendidikan Islam Tinjauan Teoritis Dan Praktis Berdasarkan Pendekatan Interdisipliner. Jakarta: Bumi Aksara.

Azwar, Saifuddin. 1998. Sikap manusia: Teori dan Pengukurannya. Yogyakarta: Pustaka Pelajar,

Berry, John W, dkk. 1999. Psikologi Lintas-Budaya Riset dan Aplikasi. Jakarta: Gramedia Pustaka Utama.

Darajat, Zakia. 1990. Ilmu Jiwa Agama. Jakarta: Bulan Bintang.

Darajat, Zakiah. 2000. Metodik Khusus Pengajaran Agama Islam. Jakarta: Bumi Aksara.

Darajat, Zakia. 2003. Metodologi Pengajaran Agama Islam. Jakarta: Bumi Aksara.

Djamarah, Syaiful Bahri. 2005. Guru Dan Anak Didik Dalam Interaksi Edukatif Suatu Pendekatan Teoritis Psikologi. Jakarta: Rineka Cipta.

Departemen Agama, 2006. Al-Qur'an dan Terjemahnya,( Bandung: Diponegoro)

Echols, John M, Hasan Shadily. 1980. Kamus Inggris Indonesia. Jakarta: Gramedia.

Fahmi, M. Agil."Upaya Guru Pendidikan Agama Islam Dalam Penanaman Nilai-Nilai Pluralisme Agama Pada Siswa Di SMA Negeri 10 Demursari Surabaya". Surabaya.

Faisal. 2005. "Upaya Guru Dalam Menciptakan Suasana Keagamaan di SMA N 6" Tesisi Megister Pendidikan Agama Islam Pada Program Pascasarjana (PPs) Institut Agama Islam Negeri (IAIN) Raden Fatah, Palembang. 
44 | BELAJEA : Jurnal Pendidikan Islam, Vol. 3, No. 1, 2018

Hans, Wehr. 1980. A Dictionary of Modern Written Arabic. London Macdonald dan Evans, Ltd.

Hawi, Akmal. 2006. Kompetensi Guru Pendidikan Agama Islam. Palembang: IAIN Raden Fatah Press.

Ihsan, Hamdani, A. Fuad Hasan. 1998. Filsafat Pendidikan Islam. Bandung: Pustaka Setia.

Jalaluddin. 1995. Psikologi Agama. Jakarta: Raja Grafindo Persada.

Jalaluddin. 1996. Teologi Islam: Interpretasi Untuk Aksi. Bandung: Mizan.

Langgulung, Hasan. 1980. Beberapa pemikiran tentang pendidikan Islam. Bandung: Al-Ma'arif.

Light, D., Keller, S., \& Calhoun, C. 1989. Sociology. New York: Alfred A. Knopf.

Ma'luf, Louis. 1977. al-Munjid fì al-Lugha. Dār al-Masyriq, Bairut.

Macionis, J. J. 1970. Society the basics. Prentice Hall, Englewood Cliffs, New Jersey.

Marimba, Ahmad Daeng. 1989. Pengantar Filsafat Pendidikan Islam. Bandung: Al Ma'arif.

Moleong, Lexy J. 1991. Metodologi Penelitian Kualitatif. Bandung: Remaja Rosdakarya. Messi dan Edi Harapan, Menanamkan Nilai Nilai Kejujuran di dalam Kegiatan Madrasah Berasrama (Boarding School), JMKSP Jurnal Manajemen, Kepemimpinan, dan Supervisi Pendidikan, Volume 1, No. 1, Juli-Desember 2017.

Muhaimin. 2002. Paradigma Pendidikan Islam Upaya Mengefektifkan Pendidikan Agama Islam Di Sekolah. Bandung: Remaja Rosdakarya.

Muhaimin, dkk. 1998. Strategi Belajar Mengajar: Penerapannya Dalam Pembelajaran Pendidikan Agama. Surabaya: Citra Media.

Muhaimin. 2004. Pengembangan Kurikulum Pendidikan Agama Islam di Sekolah, Madrasah dan Perguruan Tinggi. Jakarta: Rajawali Press.

Muhaimin, Abdul Mujid, Yusuf Mudzakkir. 2005. Kawasan dan Wawasan Studi Islam. Jakarta: Prenada Media.

Muhammad, Fadlil Al Jamali. 1993. Konsep Pendidikan Qur'ani, Sebuab Kajian Filosofis, (terj), Sol: Judi Al - Falasani Ramadhani..

Muhtadi, Ali. 2011. "Penanaman Nilai-Nilai Agama Islam Dalam Pembentukan Sikap Dan Perilaku Siswa Sekolah Dasar Islam Terpadu Luqmanul Hakim". Yogyakarta.

Nata, Abuddin. 1997. Filsafat Pendidikan Islam 1. Jakarta: Logos. 
Permana. 2008. "Upaya Orag Tua Mendidik Ketaatan Anak Melaksanakan Salat Wajib Studi Kasus Di Keluarga Nelayan Kecamatan Simpang Rimba Bangka Selatan". Tesis Megister Pendidikan Agama Islam pada Program Pascasarjana (PPs) Institut Agama Islam Negeri (IAIN) Raden Fatah, Palembang.

Rahardjo, M. Dawam. 1996. Ensiklopedi Al Qur'an, Tafsir Sosial Berdasarkan Konsep-Konsep Kunc. Jakarta: Paramadina.

Purwanto, Ngalim. 2007. Psikologi Pendidikan. Bandung: Remaja Rosdakarya..

Saleh, Abdurrahmansyah. 2000. Pendidikan Dan Keagamaan: Visi, Misi Dan Aksi. Jakarta: Gema Insani.

Nina Sultonurohmah, Strategi Penanaman Nilai Karakter Jujur Dan Disiplin Siswa, Al-Ibtida',Vol. 5, No. 2, 2017. STAI Diponegoro Tulungagung.

Sugoyono, 2015. Metodologi Penelitian Pendidikan, Bandung: Alfabeta.

Suharman. 2002. Metoda Pendidikan Moral Memasuki Era Globalisasi. Jurnal Ilmu Pendidikan Islam IAIN Sunan Kalijaga Yogyakarta. Vol 4, N0.3. P. 159167.

Tafsir, Ahmad. 1984. Ilmu Pendidikan dalam Perspektif Islam. Bandung: Rosda Karya.

Tafsir, Ahmad. 1996. Metodologi Pengajaran Agama Islam. Bandung: Remaja Rosdakarya.

Tim Penyusun Kamus Departemen Pendidikan Dan Kebudayaan. 1995. Kamus Besar Bahasa Indonesia. Jakarta: Balai Pustaka.

Undang-Undang Republik Indonesia Nomor 20 Tahun 2003 tentang SISDIKNAS dan Peraturan Pemerintah tentang Penyelenggaraan Pendidikan serta Wajib Belajar. Bandung: Citra Umbara

Ungusari, Erlisia 2015. Kejujuran dan Ketidakjujuran Akademik pada Siswa SMA yang Berbasis Agama. Fakultas Psikologi Universitas Muhammadiyah Surakarta.

Agus Wibowo, 2012. Pendidikan Karakter: Strategi Membangun karakter Bangsa Berperadaban, Yogyakarta: Pustaka Pelajar.

W.J.S. Poerwadarminta. 1991. Kamus Umum Bahasa Indonesia. Jakarta: Balai Pustaka. 
46 | BELAJEA : Jurnal Pendidikan Islam, Vol. 3, No. 1, 2018

Halaman ini sengaja dikosongkan 